\title{
Ten years of the Hunter Outcome Survey (HOS): insights, achievements, and lessons learned from a global patient registry
}

\author{
Joseph Muenzer ${ }^{1}$, Simon A. Jones², Anna Tylki-Szymańska ${ }^{3}$, Paul Harmatz ${ }^{4}$, Nancy J. Mendelsohn, ${ }^{5,6}$, \\ Nathalie Guffon ${ }^{7}$, Roberto Giugliani ${ }^{8}$, Barbara K. Burton ${ }^{9}$, Maurizio Scarpa ${ }^{10,11}$, Michael Beck ${ }^{12}$, Yvonne Jangelind ${ }^{13}$, \\ Elizabeth Hernberg-Stahl ${ }^{14}$, Maria Paabøl Larsen ${ }^{15,17}$, Tom Pulles ${ }^{16,18}$ and David A. H. Whiteman ${ }^{15^{*}}$
}

\begin{abstract}
Mucopolysaccharidosis type II (MPS II; Hunter syndrome; OMIM 309900) is a rare lysosomal storage disease with progressive multisystem manifestations caused by deficient activity of the enzyme iduronate-2-sulfatase. Diseasespecific treatment is available in the form of enzyme replacement therapy with intravenous idursulfase (Elaprase ${ }^{\circledast}$, Shire). Since 2005, the Hunter Outcome Survey (HOS) has collected real-world, long-term data on the safety and effectiveness of this therapy, as well as the natural history of MPS II. Individuals with a confirmed diagnosis of MPS II who are untreated or who are receiving/have received treatment with idursulfase or bone marrow transplant can be enrolled in HOS. A broad range of disease- and treatment-related information is captured in the registry and, over the past decade, data from more than 1000 patients from 124 clinics in 29 countries have been collected. Evidence generated from HOS has helped to improve our understanding of disease progression in both treated and untreated patients and has extended findings from the formal clinical trials of idursulfase. As a long-term, global, observational registry, various challenges relating to data collection, entry, and analysis have been encountered. These have resulted in changes to the HOS database platform, and novel approaches to maximize the value of the information collected will also be needed in the future. The continued evolution of the registry should help to ensure that HOS provides further insights into the burden of the disease and patient care and management in the coming years.
\end{abstract}

Keywords: Patient registry, Mucopolysaccharidosis type II, Hunter syndrome, Enzyme replacement therapy

\section{Background}

Randomized controlled clinical trials are the gold standard for assessing the safety and efficacy of new drugs. However, they typically measure only the short-term impact of therapies in limited, strictly controlled patient populations, using standardized treatment protocols [1]. As a result, clinical data obtained in the real-world setting over a longer period of follow-up in larger patient groups are increasingly required to complement and extend findings from clinical trials. This is particularly true for rare diseases, where the number of patients available to participate in trials is often small and the natural disease course may be poorly defined or highly

\footnotetext{
* Correspondence: dwhiteman@shire.com

${ }^{15}$ Shire Human Genetic Therapies, Inc., 300 Shire Way HA100-310, Lexington, MA 02421, USA

Full list of author information is available at the end of the article
}

variable [2]. Patient registries are valuable sources of information on disease course and treatment outcomes, and there are now more than 600 rare disease registries in Europe alone [3, 4].

One group of diseases for which patient registries have been particularly valuable is the lysosomal storage diseases (LSD). These are rare, inherited, progressive disorders caused by defects in lysosomal function, and they typically have a highly variable clinical course. Patient registries have been established for a number of LSD, including Gaucher disease, Fabry disease, Pompe disease, and mucopolysaccharidosis types I, II, IV, and VI [5-12], and have provided important insights into the natural history of these conditions and the long-term effects of specific therapies.

Mucopolysaccharidosis type II (MPS II; Hunter syndrome; OMIM 309900) is a rare X-linked disorder 
caused by deficient activity of iduronate-2-sulfatase (I2S) [13-15] (see Table 1). The disease primarily affects males (estimated incidence, 0.6-1.3 in 100,000 live male births) although a small number of female patients have been described [13, 15, 16]. Historically, management of MPS II was palliative, although two treatment options, enzyme replacement therapy (ERT) and hematopoietic stem cell transplantation (HSCT), are currently available $[17,18]$. ERT with recombinant I2S (idursulfase, Elaprase $^{\bullet}$, Shire, Lexington, MA, USA) became available in the USA in 2006 and in Europe in 2007, and stabilizes many of the somatic signs and symptoms of MPS II [18-22].

The Hunter Outcome Survey (HOS) was established in 2005 and the data collected have been used to address post-approval commitments relating to Elaprase. This global, multicentre, longitudinal, observational registry collects real-world data on the clinical presentation and progression of MPS II, and the long-term safety and effectiveness of intravenous ERT with Elaprase. Here, we discuss the contributions that data collected in HOS have made to our knowledge of MPS II and share insights into the nature of this type of clinical study, lessons learned during the past decade, and the new challenges to be overcome in the future.

\section{Registry design and objectives}

HOS is a long-term open-ended global registry designed to collect information on patients with MPS II based on data obtained during routine patient visits and assessments [12]. The registry is open to individuals with a biochemically or genetically confirmed diagnosis of MPS II, including those who are untreated, those who are receiving treatment with Elaprase, and those who have undergone HSCT. Patients receiving ERT with a product

Table 1 What is mucopolysaccharidosis type II (MPS II)?

- First described in two brothers by Dr Charles A. Hunter in 1917.

- Caused by deficient activity of the lysosomal enzyme iduronate-2sulfatase (EC 3.1.6.13), which catalyses a step in the catabolism of the glycosaminoglycans (GAG) dermatan sulfate and heparan sulfate. The accumulation of these in tissues and organs throughout the body contributes to the chronic, progressive, multisystemic manifestations of MPS II [14, 15].

- The initial clinical signs and symptoms typically emerge within the first few years of life and include recurrent respiratory infections, coarse facial features, joint stiffness, otitis media, hearing loss, umbilical/inguinal hernias, and hepatosplenomegaly [45].

- The severity of the disease spans a broad range. For clinical purposes, patients are generally considered to fall into one of two categories according to the presence or absence of cognitive impairment. All patients will experience somatic disease manifestations, although progression may be slower in individuals without cognitive impairment $[14,15]$. About twothirds of patients will display progressive central nervous system involvement, initially resulting in learning impairment and abnormal behaviour, followed by the development of profound cognitive impairment [12]. other than Elaprase are not eligible for inclusion. Written informed consent is obtained from each patient, their parents, or legal representative. Data from individuals who are alive at HOS entry (prospective patients) can be entered; where local regulations permit, information from those who died before enrollment (historical patients) is also collected.

A broad range of disease- and treatment-related information is captured in the registry (both prospectively and retrospectively), with the primary objective of monitoring the long-term safety and effectiveness of ERT with Elaprase in patients with MPS II (registry endpoints are shown in Table 2). Secondary objectives of HOS are to elucidate the natural history of the disease in untreated patients and to monitor dosing regimens of Elaprase in treated patients. In addition, participating patients and/or their parents can complete the Hunter Syndrome Functional Outcomes for Clinical Understanding Scale (HS-FOCUS) questionnaire, which is used to assess the impact of MPS II on patients' daily lives. The observational nature of the registry means that there is no predefined sample size and that a hypothesisfree approach is employed. As a result, any data analyses are considered to be exploratory.

HOS is operational in many countries around the world. The registry has grown significantly over the past 10 years, and as of January 2016, 1096 patients from 124 clinics in 29 countries have been enrolled (Fig. 1). This

Table 2 Registry endpoints

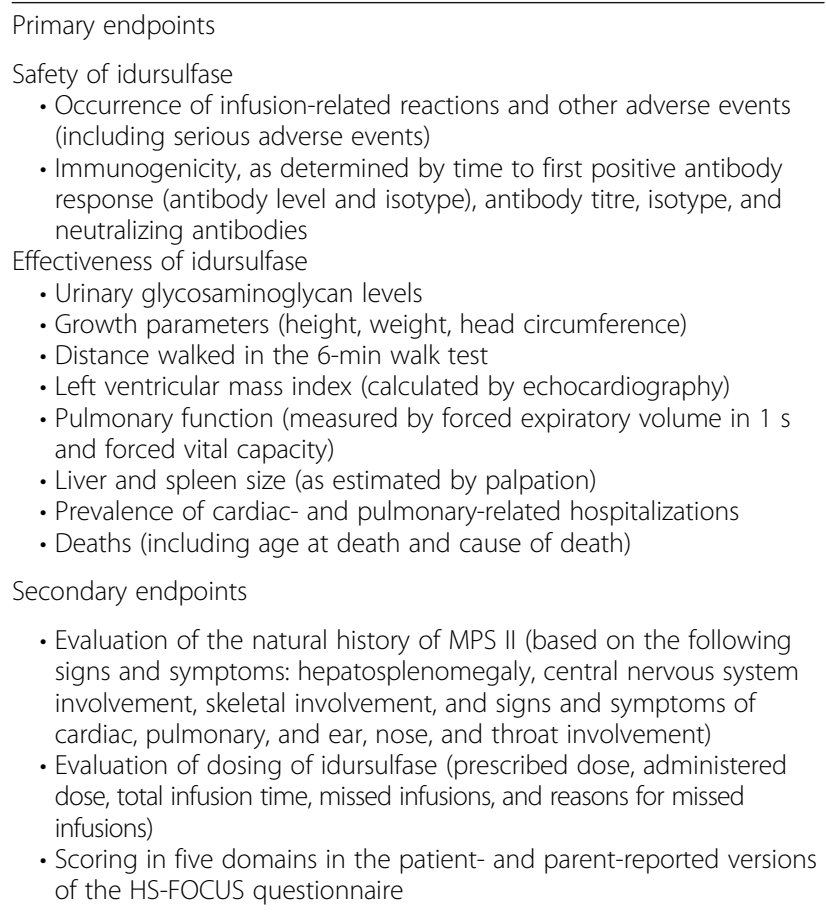

HS-FOCUS Hunter Syndrome Functional Outcomes for Clinical Understanding Scale, MPS II mucopolysaccharidosis type II 


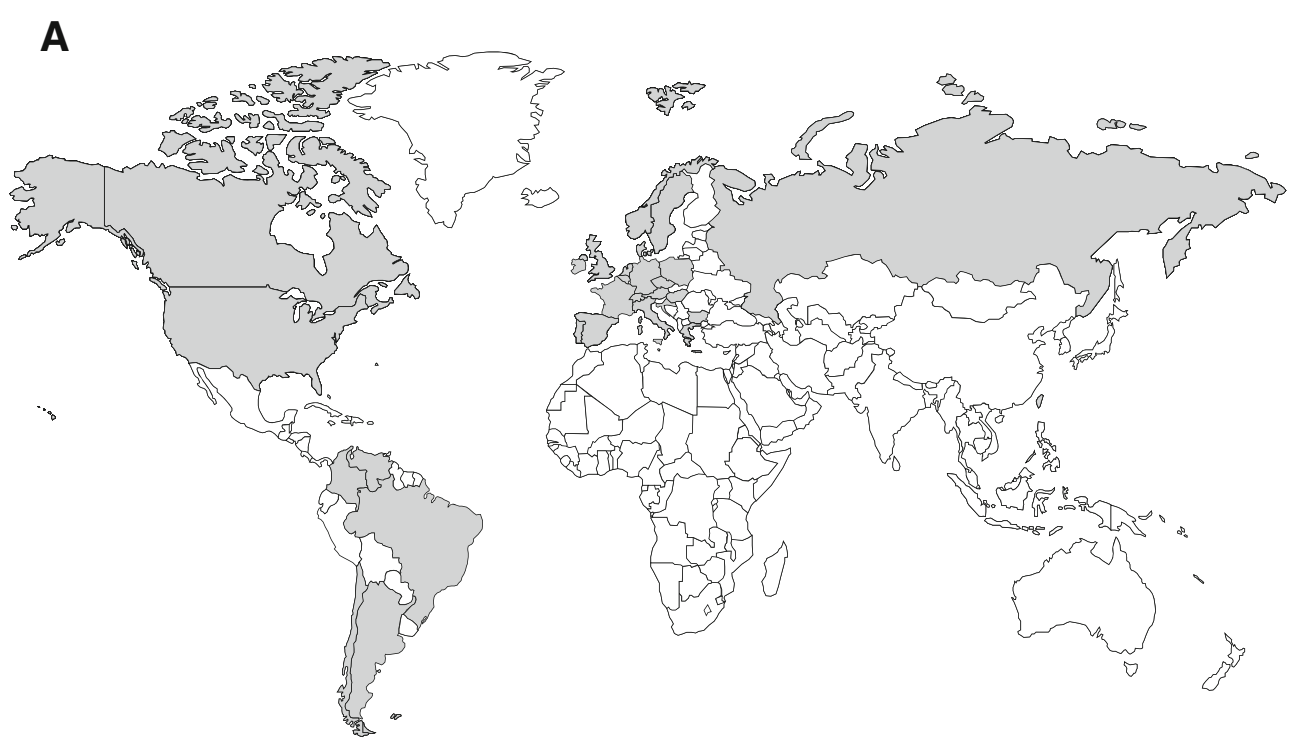

\begin{tabular}{|l|c|}
\hline Year started & 2005 \\
\hline Continents & 4 \\
\hline Countries & 29 \\
\hline Sites & 124 \\
\hline Total number of patients & 1096 \\
\hline$\quad$ Number of historical patients & 149 \\
\hline Number of prospective patients & 947 \\
\hline Median age at HOS entry $(\mathrm{n}=947)$ & 8.2 years \\
\hline Median age at diagnosis $(\mathrm{n}=847)$ & 3.3 years \\
\hline Median length of time in HOS $(\mathrm{n}=947)$ & 38.8 months \\
\hline Number of patients with cognitive impairment at any time & 530 \\
\hline Number of patients who have received ERT with idursulfase & 788 \\
\hline Number of patients who have undergone HSCT & 26 \\
\hline
\end{tabular}

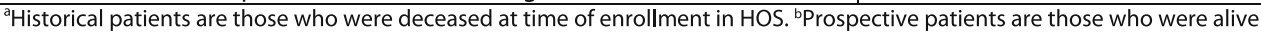
at enrollment.

Data as of January 2016

ERT, enzyme replacement therapy; HSCT, hematopoietic stem cell transplantation.

\section{B}

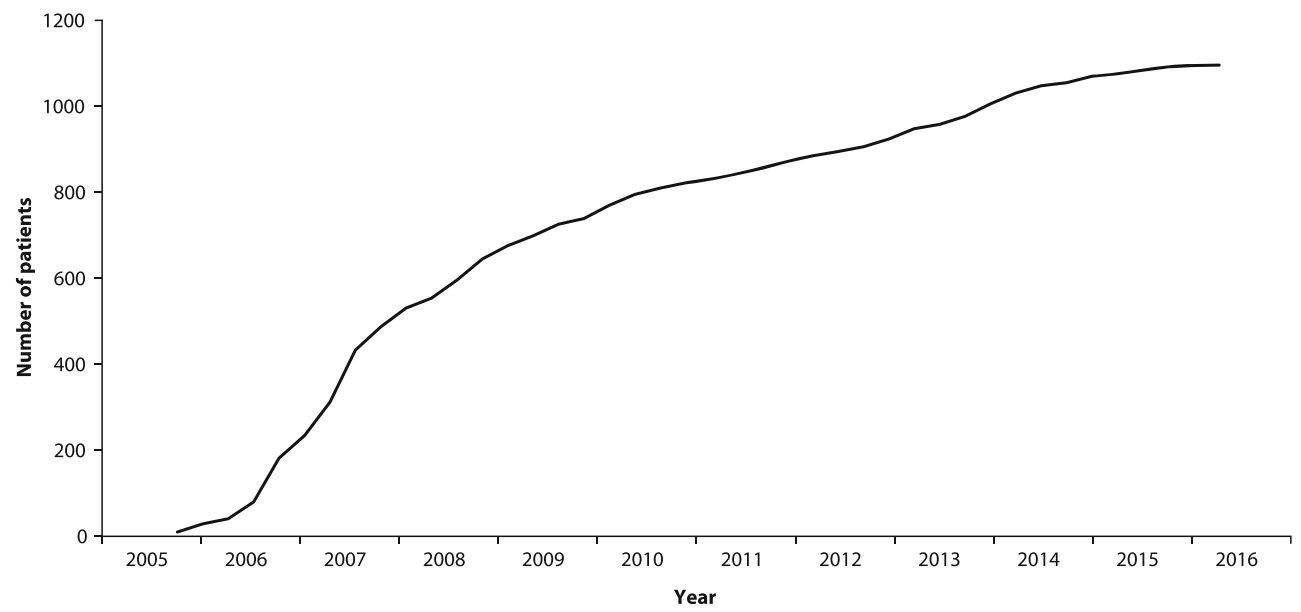

Fig. 1 Key facts about the Hunter Outcome Survey. a The global reach of HOS. Countries with active HOS sites are indicated in grey. b Number of patients enrolled in HOS since 2005 


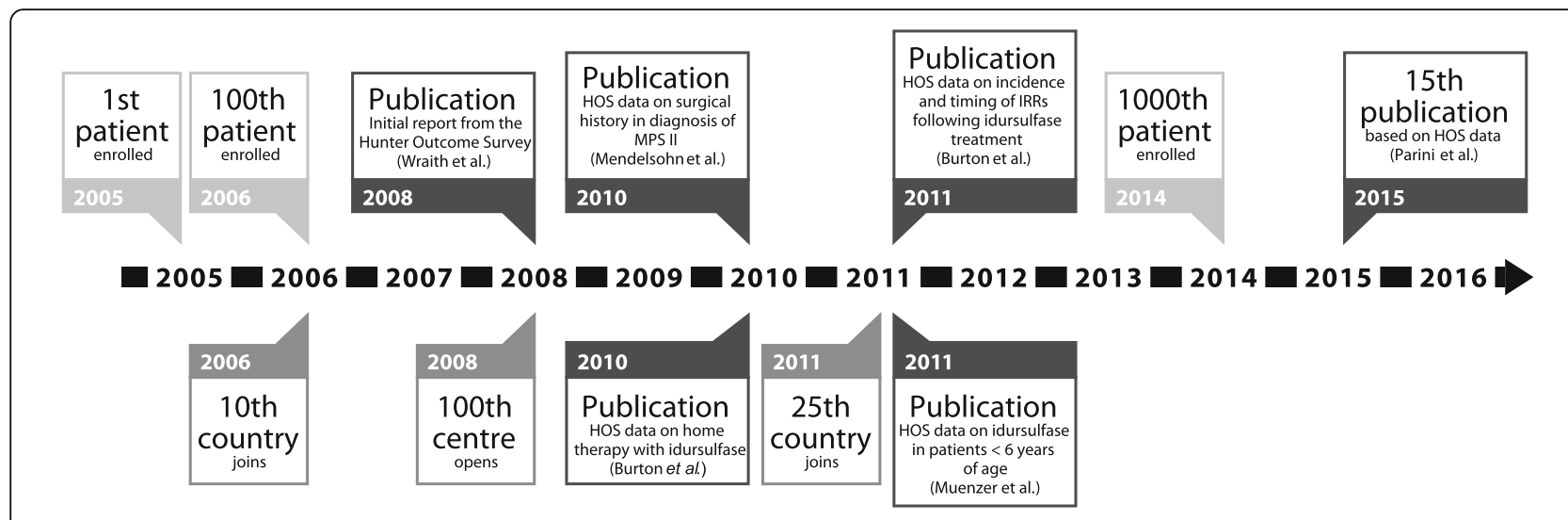

\section{Published HOS articles}

\begin{tabular}{|c|c|c|}
\hline Title & Authors & Reference \\
\hline $\begin{array}{l}\text { The natural history of growth in patients with Hunter } \\
\text { syndrome: data from the Hunter Outcome Survey (HOS) }\end{array}$ & Parini Ret al. & $\begin{array}{l}\text { Mol Genet Metab 2016;117:438- } \\
446\end{array}$ \\
\hline $\begin{array}{l}\text { The effect of idursulfase on growth in patients with Hunter } \\
\text { syndrome: data from the Hunter Outcome Survey (HOS) }\end{array}$ & Jones SA et al. & $\begin{array}{l}\text { Mol Genet Metab 2013;109:41- } \\
48\end{array}$ \\
\hline $\begin{array}{l}\text { Development of a mnemonic screening tool for identifying } \\
\text { subjects with Hunter syndrome }\end{array}$ & Cohn Getal. & Eur J Pediatr 2013;172:965-970 \\
\hline $\begin{array}{l}\text { Hearing loss in patients with mucopolysaccharidosis II: } \\
\text { data from HOS - the Hunter Outcome Survey }\end{array}$ & Keilmann A et al. & $\begin{array}{l}\text { J Inherit Metab Dis 2012;35:343- } \\
353\end{array}$ \\
\hline $\begin{array}{l}\text { Prevalence and characterization of cardiac involvement in } \\
\text { Hunter syndrome }\end{array}$ & Kampmann C et al. & J Pediatr 2011;159:327-331.e2 \\
\hline $\begin{array}{l}\text { Incidence and timing of infusion-related reactions in } \\
\text { patients with mucopolysaccharidosis type II (Hunter } \\
\text { syndrome) on idursulfase therapy in the real-world setting: } \\
\text { a perspective from the Hunter Outcome Survey (HOS) }\end{array}$ & $\begin{array}{l}\text { Burton BK, } \\
\text { Whiteman DA }\end{array}$ & $\begin{array}{l}\text { Mol Genet Metab 2011;103:113- } \\
120\end{array}$ \\
\hline $\begin{array}{l}\text { Idursulfase treatment of Hunter syndrome in children } \\
\text { younger than } 6 \text { years: results from the Hunter Outcome } \\
\text { Survey }\end{array}$ & Muenzer J et al. & Genet Med 2011;13:102-109 \\
\hline $\begin{array}{l}\text { Importance of surgical history in diagnosing } \\
\text { mucopolysaccharidosis type II (Hunter syndrome): data } \\
\text { from the Hunter Outcome Survey }\end{array}$ & $\begin{array}{l}\text { Mendelsohn N } \\
\text { et al. }\end{array}$ & Genet Med 2010;12:816-822 \\
\hline $\begin{array}{l}\text { First experience of enzyme replacement therapy with } \\
\text { idursulfase in Spanish patients with Hunter syndrome } \\
\text { under } 5 \text { years of age: case observations from the Hunter } \\
\text { Outcome Survey (HOS) }\end{array}$ & $\begin{array}{l}\text { Alcalde-Martín C } \\
\text { et al. }\end{array}$ & $\begin{array}{l}\text { Eur J Med Genet 2010;53:371- } \\
377\end{array}$ \\
\hline $\begin{array}{l}\text { Home treatment with intravenous enzyme replacement } \\
\text { therapy with idursulfase for mucopolysaccharidosis type } \\
\text { II: data from the Hunter Outcome Survey }\end{array}$ & Burton BK et al. & $\begin{array}{l}\text { Mol Genet Metab 2010;101:123- } \\
129\end{array}$ \\
\hline $\begin{array}{l}\text { Orthopedic manifestations in patients with } \\
\text { mucopolysaccharidosis type II (Hunter syndrome) enrolled } \\
\text { in the Hunter Outcome Survey }\end{array}$ & Link B et al. & Orthop Rev (Pavia) 2010;2:e16 \\
\hline $\begin{array}{l}\text { Mortality and cause of death in mucopolysaccharidosis } \\
\text { type II - a historical review based on data from the Hunter } \\
\text { Outcome Survey (HOS) }\end{array}$ & Jones SA et al. & $\begin{array}{l}\text { J Inherit Metab Dis 2009;32:534- } \\
543\end{array}$ \\
\hline Initial report from the Hunter Outcome Survey & Wraith JE et al. & Genet Med 2008;10:508-516 \\
\hline $\begin{array}{l}\text { World-wide experience in the treatment of } \\
\text { mucopolysaccharidosis type II: the Hunter Outcome } \\
\text { Survey (HOS) registry }\end{array}$ & del Toro-Riera M & $\begin{array}{l}\text { Rev Neurol 2008;47 (Suppl 2): } \\
\text { S3-S7 }\end{array}$ \\
\hline $\begin{array}{l}\text { Follow-up of patients with Hunter syndrome: the Hunter } \\
\text { Outcome Survey (HOS) registry }\end{array}$ & del Toro-Riera M & $\begin{array}{l}\text { Rev Neurol 2007;44 (Suppl 1): } \\
\text { S13-S17 }\end{array}$ \\
\hline
\end{tabular}

Fig. 2 Key landmarks in the history of HOS and associated publications 
is a major achievement considering the rarity of MPS II, and HOS is the largest global source of data from patients with the disease. As with all clinical studies, each participating clinic has an Investigator and the registry complies with all relevant regulations and best practices for ethical conduct. Strategic direction and long-term scientific planning are overseen by a Steering Committee, which comprises an international group of physicians with expertise in a range of different disciplines.

\section{Achievements of HOS over the past decade} Understanding the clinical presentation and progression of MPS II

Analyses of data from the large number of patients in HOS have made a significant contribution to our understanding of the clinical presentation and progression of the disease [12, 23-29] (Fig. 2). For example when the registry was initiated, quantitative data about the timing and prevalence of the clinical manifestations of MPS II were limited. One of the first analyses therefore looked at the time of symptom onset [12]. This demonstrated that the median age of symptom onset was 1.5 years, with otitis media and abdominal hernia the earliest presenting clinical features [12], extending and validating some of the early descriptive reports of patients with MPS II in a larger sample of over 200 patients. This information is particularly valuable because physicians may care for only a small number of individuals with the disease, if any, during their career.

The diagnosis of MPS II is challenging and often delayed because of the non-specific and highly variable nature of the clinical presentation of the disease [30]. An analysis of surgical history in prospective patients in the registry revealed a distinct pattern of procedures that was common in individuals with MPS II [28]. In particular, tympanostomy, inguinal hernia repair, and carpal tunnel release were performed in a greater proportion of the study population than in the general population, and repeat operations for hernia repair and carpal tunnel release were common in patients with MPS II [28]. It is hoped that knowledge of this characteristic pattern of surgical procedures, together with a greater awareness of the early signs and symptoms of the disease among physicians from different medical specialties, will help to facilitate prompt diagnosis and management of patients with MPS II.

\section{Insights into patient management}

The pivotal clinical trials demonstrated that idursulfase was generally well tolerated, with a similar safety profile to that reported for ERT in patients with other MPS [19, 21, 22], and data from HOS have enabled these findings to be extended [31-37]. In particular, an analysis of data from
104 patients treated with idursulfase for at least 1 year demonstrated that, of the 33 patients who had an infusionrelated reaction (IRR), the majority $(28 / 33 ; 85 \%)$ experienced their first IRR during the first 3 months of treatment. In addition, most IRRs were mild or moderate in severity and could be managed without interrupting treatment [33]. This information enabled the development of guidance on the management of IRRs [33].

The broad age range of patients enrolled in the registry also allowed an analysis to be performed of safety and preliminary clinical outcomes in patients younger than 6 years of age [37], extending knowledge beyond that obtained from the clinical trials of idursulfase which were restricted to individuals older than 5 years. No new safety issues were identified, and the data suggested that idursulfase has a beneficial effect on palpable liver size [37]. These findings, together with data from subsequent studies in young patients [22], have helped to make idursulfase available to children younger than 6 years old, permitting early initiation of treatment, which is important for patients with this progressive disease [38].

HOS has also provided useful information on the safety and feasibility of home infusions with idursulfase. This option, available in several countries, can help to ease the burden of the disease and its management on patients and their families [39]. A study of 59 individuals who received home therapy for at least 12 months reported that five IRRs occurred in two patients [32]. These IRRs were readily managed at home by either slowing or stopping the infusion and by appropriate pretreatment with antihistamines. These findings enabled the development of guidelines and an algorithm to facilitate the transition of patients with MPS II from receiving therapy in a clinical setting to receiving infusions at home [32]. The increasing number of treated patients enrolled in the registry should lead to further key insights into the safety and effectiveness of ERT with idursulfase in the future. It should be noted that although patients who have received HSCT are eligible for inclusion in the registry, only a small number have been enrolled (Fig. 1). In addition, the assessment of outcomes in these patients is beyond the scope of HOS and so the safety and effectiveness of HSCT in patients with MPS II have not been assessed using data from the registry.

Finally, it is increasingly recognized in the field of rare diseases that patient-reported outcomes and patient involvement in research are important for facilitating measurement of treatment benefits and quality of life and for ensuring that the care provided is patient centred $[1,3]$. The HS-FOCUS questionnaire was developed to obtain insight into the effects of MPS II on the daily lives of patients and their parents and/or caregivers $[40,41]$. HS-FOCUS data have been collected in HOS since 2006, and it is hoped that this information will 
enhance our understanding of the impact of MPS II on the daily lives of patients and their families and potentially lead to improvements in patient care.

\section{Challenges encountered in HOS \\ Data collection and analysis}

Although patient registries provide valuable longitudinal data from a large, broad patient population, it is important to take into account the differences between data collected in a formal clinical trial and those collected in a registry. HOS is non-interventional and is designed to acquire 'real-world' data from individuals with MPS II during routine clinical practice [12]. As a result, the methods and techniques used for clinical assessments and laboratory assays are not standardized across participating clinics. In addition, the frequency of follow-up visits may vary considerably between patients. It is also important to note that the clinical assessments performed for each patient may differ as a result of variation in disease severity between patients and differences in the standards of care and resources between countries. For example, there is no standard method that is used in all countries for assessing the cognitive and behavioral aspects of MPS II [42].

The multisystem, progressive nature of MPS II also means that each patient typically undergoes numerous clinical and biochemical assessments [43] and is often seen by many different specialists, such as cardiologists, neurologists and otorhinolaryngologists $[18,43]$. These specialists are not necessarily directly involved or familiar with HOS, and the specialist clinical assessments and investigations are not always performed at the same site where data entry takes place or at routine visits with the managing physician. The collection of complete, highquality, uniform data for all patients is therefore often difficult and this can make data analyses particularly challenging. For example, it is not always possible to collect a full set of longitudinal information for each patient. As a result, the number of patients whose data can be used for analysis varies depending on the clinical parameters of interest and the time frame studied. There is also no formal control group and so there are limitations associated with analyses of idursulfase treatment effects. Although a number of untreated patients have been enrolled in the registry, differences in clinical characteristics, the care received, the frequency of clinical visits, and the availability of follow-up data mean that comparisons with treated patients are not straightforward.

Several strategies have been introduced to help participating clinics to increase data completeness. These include the provision of data entry support and improvements to the HOS database platform to make it more user-friendly. A set of key clinical core data variables comprising the minimum data set that should ideally be captured for each patient has also been identified and clinics are asked to focus on collecting these data for each of their patients. In addition, HOS will need to continue to evolve to ensure that the data captured accurately reflect current routine patient care in different countries, as well as new developments in our understanding of MPS II and its management. In the future, it will be important to take advantage of technological advances in database functionality, for example to allow the entry of items such as magnetic resonance imaging scans, and to make sure that the database is updated to capture results from new clinical assessments and tools that are developed in the future. This should help to ensure that the value of the data collected in the registry and the analyses performed are maximized and meet the demands of multiple stakeholders.

\section{Meeting regulatory requirements}

As a condition of the marketing authorization for Elaprase, regulatory agencies in European and other countries (including USA and Canada) required additional long-term safety and effectiveness data in patients with MPS II being treated with idursulfase. Data requirements for specific long-term outcome measures have continued to evolve over time and currently include assessments of pulmonary and cardiovascular morbidity and mortality, urinary glycosaminoglycan levels, and antibody levels.

It is important to note that there are a number of challenges associated with assessing these treatment outcomes. For example, pulmonary function can be assessed using forced vital capacity (FVC) testing and the 6-min walk test (6MWT). However, these tests are unsuitable for particular patient subgroups (e.g. those under 5 years of age and individuals with progressive cognitive impairment) and may not be performed as part of routine patient visits [22, 38, 44]. This makes the evaluation of treatment effects in these patients particularly challenging. The progressive, multisystemic nature of MPS II also means that it is often impossible to collect full, clinically meaningful data sets for many patients, particularly those with advanced disease. Furthermore, baseline data are not available for a substantial number of patients because of the voluntary, noninterventional nature of the registry and because patients may begin treatment many years before HOS entry. As a result, it is difficult to demonstrate long-term treatment effectiveness based on the information available in the database and it is likely that new methods will need to be developed and implemented to address this.

\section{Conclusions}

Building on its primary objective of documenting the long-term safety and effectiveness of idursulfase in 
patients with MPS II, HOS has provided valuable information on the clinical presentation and progression of the disease, as well as its management. These are considerable achievements, and the registry has provided information on a larger, broader patient population than has been, or could be, studied in formal clinical trials. The multinational nature of HOS and the engagement of experts in MPS II are key strengths of the registry and will be essential to ensure that the registry continues to provide valuable insight into the similarities and differences in patient demographics and management between countries.

A number of challenges will, however, need to be overcome. As further developments are made in the management of patients with this progressive disorder, HOS will need to evolve to ensure that the data collected continue to reflect current practice for patient management accurately and can be used to evaluate the long-term effects of treatment. Patient-reported outcomes are also increasingly being recognized as having an important role in complementing traditional clinical data when assessing the value of treatment in rare diseases [1, 3]; therefore, the continued collection of data from the HSFOCUS questionnaire remains a priority. Achieving further improvement in the quality and comprehensiveness of the data will remain an important goal, and new initiatives to facilitate this are likely to be required. One approach may be to enable direct data entry by patients and/or their family members, although the feasibility and potential risks of such an approach would need to be considered carefully and discussed with all relevant stakeholders. In addition, it is important to note that idursulfase does not cross the blood-brain barrier and so treatment of neurological aspects of the disease remains challenging. For this reason, several novel approaches are currently being investigated, with the aim of improving the care of patients with MPS II and neurological involvement in the future.

Over the next decade, the implementation of new approaches to aid data collection and entry, and to enhance methods for the evaluation of treatment effects over the long term, should help to ensure that the value of the information collected in HOS is maximized. Ultimately, this will help to ensure that this registry continues to improve our understanding of MPS II and its management in real-world clinical practice.

\footnotetext{
Abbreviations

ERT: Enzyme replacement therapy; HOS: Hunter Outcome Survey; HS-FOCUS: Hunter Syndrome Functional Outcomes for Clinical Understanding Scale;

HSCT: hematopoietic stem cell transplant; I2S: Iduronate-2-sulfatase; IRR: Infusionrelated reaction; MPS II: Mucopolysaccharidosis type II
}

\section{Acknowledgements}

We would like to thank all those involved in HOS for their valuable contributions, in particular the patients enrolled in HOS and their families, as well as the HOS Investigators and the study coordinators. We would also like to thank Barbara Wedehase (National MPS Society, USA) and Christine Lavery (MPS Society, UK) for their contribution to patient recruitment to HOS, and Susan Wieting (Shire, Zug, Switzerland) for valuable input during the drafting of this review. Medical writing support was provided to the authors by Dr Laura Pearce of Oxford PharmaGenesis (Oxford, UK).

\section{Funding}

This study was sponsored and funded by Shire. Data analyses were performed by Shire under the direction of the authors. No honoraria, grants, or other forms of payment were made to the authors for the writing of the manuscript. Medical writing support was funded by Shire.

\section{Availability of data and materials}

The datasets supporting this article are included within the article.

\section{Authors' contributions}

All authors contributed to the conception of the article, were involved in drafting the article and revising it critically for important intellectual content. JM and DW were major contributors in writing the manuscript. All authors read and approved the final manuscript and agree to be accountable for all aspects of the work

\section{Competing interests}

Professor Muenzer is a consultant to BioMarin, Eloxx, Genzyme (a Sanofi company), Green Cross, Janssen Pharmaceuticals, PTC Therapeutics, and Shire. He also serves on advisory boards for BioMarin, Genzyme (a Sanofi company), and Shire. He is principal investigator for phase $1 / 2$ and phase $2 / 3$ trials, sponsored by Shire, that investigate intrathecal enzyme replacement therapy for patients with the severe form of Hunter syndrome. Dr Jones has received honoraria for speaking engagements and assistance with travel to conferences from Shire; he is also engaged in research projects with Shire, Genzyme (a Sanofi Company), BioMarin, Ultragenyx Pharmaceutical, Inc., and Alexion Pharmaceuticals, Inc.

Professor Tylki-Szymańska has received travel grants and speaker fees from BioMarin, Genzyme (a Sanofi company), Shire, and Synageva BioPharma. Dr Harmatz has provided consulting support to, and received grant support and honoraria for speaking engagements from, Shire, BioMarin, Genzyme (a Sanofi company), PTC Therapeutics, Alexion/Enobia, ArmaGen, Chiesi, and REGENXBIO.

Dr Mendelsohn is engaged in ongoing research projects with Shire and BioMarin.

Dr Guffon has received research funds from Shire, Genzyme (a Sanofi company), Sanofi, Swedish Orphan Biovitrum (SOBI), BioMarin, Lucane Pharma, Nutricia, and Zymenex. She has also received institutional grants for clinical trials, HOS, and other registries, is involved in expert boards, and has received investigator fees.

Professor Giugliani has received travel grants from BioMarin, Genzyme (a Sanofi company), and Shire, research grants from Actelion Pharmaceuticals, Alexion, Amicus, BioMarin, Genzyme (a Sanofi company) and Shire, and honoraria for speaking engagements from Actelion Pharmaceuticals, Alexion, Amicus, BioMarin, Genzyme (a Sanofi company), PTC Therapeutics, and Shire. Dr Burton has received consulting fees from Shire, Armagen, BioMarin, Genzyme (a Sanofi company), Hyperion, Nora Therapeutics, and REGENXBIO and has performed contracted research for Shire, Alexion Pharmaceuticals, Inc., Armagen, BioMarin, Cytonet LLC, Genzyme (a Sanofi company), Synageva BioPharma, and Ultragenyx Pharmaceutical, Inc. Professor Scarpa has received grants, travel support, and honoraria from BioMarin, Genzyme (a Sanofi company), and Shire.

Professor Beck has received honoraria, travel support, and unrestricted grants from Actelion Pharmaceuticals, BioMarin, Genzyme (a Sanofi company), and Shire.

Ms Jangelind is a director of Jangelind Consulting $A B$ and a consultant to Ultagenyx Pharmaceutical, Inc.

Ms Hernberg-Stahl is a director of Late Phase Solutions Europe AB.

Ms Paabøl Larsen is a full-time employee of Shionogi, Inc., and was previously a full-time employee of Shire.

Dr Pulles is a full-time employee of Ultragenyx Pharmaceutical, Inc., and was previously a full-time employee and shareholder of Shire.

Dr Whiteman is a full-time employee and shareholder of Shire. 


\section{Consent for publication}

Each patient, their parents, or a legal representative provided informed consent for publication of data.

\section{Ethics approval and consent to participate}

Independent Review Board/Ethics Committee approval was obtained for all participating centres. HOS is conducted in accordance with Good Pharmacoepidemiological Practices (GPP), Good Research for Comparative Effectiveness principles, and the relevant principles of the International Conference on Harmonisation (ICH) Good Clinical Practice (GCP) guidelines (ICH E6). Each patient, their parents, or a legal representative provided signed and dated written informed consent for participation in HOS. Data from deceased patients from outside the UK were entered with consent from their legally authorized representative. For those deceased patients from the UK, permission was obtained from the ethics committee that approved HOS.

\section{Publisher's Note}

Springer Nature remains neutral with regard to jurisdictional claims in published maps and institutional affiliations.

\section{Author details}

'Department of Pediatrics, University of North Carolina at Chapel Hill, Chapel Hill, NC, USA. ${ }^{2}$ Willink Unit, Manchester Centre for Genomic Medicine, St Mary's Hospital, Manchester and Academic Health Sciences Centre, Central Manchester University Hospitals NHS Foundation Trust, Manchester, UK. ${ }^{3}$ Department of Pediatric Nutrition and Metabolic Diseases, The Children's Memorial Health Institute, Warsaw, Poland. ${ }^{4}$ UCSF Benioff Children's Hospital Oakland, Oakland, CA, USA. ${ }^{5}$ Genomic Medicine Program, Children's Hospitals and Clinics of Minnesota, Minneapolis, MN, USA. ${ }^{6}$ Department of Pediatrics, Division of Genetics, University of Minnesota, Minneapolis, MN, USA. ${ }^{7}$ Centre de Référence des Maladies Héréditaires du Métabolisme, Hôpital Femme Mère Enfant, Bron, France. ${ }^{8}$ Department of Genetics/UFRGS and INAGEMP, Medical Genetics Service/HCPA, Porto Alegre, Brazil. ' Division of Genetics, Birth Defects and Metabolism, Ann \& Robert H. Lurie Children's Hospital of Chicago, Northwestern University, Chicago, IL, USA. ${ }^{10}$ Rare Disease Centre, Helios Dr Horst Schmidt Clinic, Wiesbaden, Germany. ${ }^{11}$ Department of Women's and Children's Health, University of Padova, Padova, Italy. ${ }^{12}$ Department of Pediatrics, University Medical Center, Johannes Gutenberg University, Mainz, Germany. ${ }^{13}$ Jangelind Consulting AB, Stockholm, Sweden. ${ }^{14}$ Late Phase Solutions Europe AB, Täby, Sweden. ${ }^{15}$ Shire Human Genetic Therapies, Inc., 300 Shire Way HA100-310, Lexington, MA 02421, USA. ${ }^{16}$ Shire, Zug, Switzerland. ${ }^{17}$ Present address: Shionogi, Inc., Florham Park, NJ, USA.

${ }^{18}$ Present address: Ultragenyx Pharmaceutical, Inc., Basel, Switzerland.

Received: 19 December 2016 Accepted: 13 April 2017

\section{Published online: 02 May 2017}

\section{References}

1. Potter BK, Khangura SD, Tingley K, Chakraborty P, Little J. Translating raredisease therapies into improved care for patients and families: what are the right outcomes, designs, and engagement approaches in health-systems research? Genet Med. 2016;18(2):117-23.

2. Jones S, James E, Prasad S. Disease registries and outcomes research in children: focus on lysosomal storage disorders. Paediatr Drugs. 2011;13(1):33-47.

3. Registries for Evaluating Patient Outcomes: A User's Guide. In: Gliklich RE, Dreyer NA, Leavy MB, editors. Registries for Evaluating Patient Outcomes: A User's Guide. 3rd ed. Rockville: Agency for Healthcare Research and Quality (US); 2014.

4. Rare Disease Registries in Europe. Orphanet Report Series, Rare Diseases collection [http://www.orpha.net/orphacom/cahiers/docs/GB/Registries.pdf]. Accessed 23 Apr 2017.

5. Byrne BJ, Kishnani PS, Case LE, Merlini L, Muller-Felber W, Prasad S, van der Ploeg A. Pompe disease: design, methodology, and early findings from the Pompe Registry. Mol Genet Metab. 2011;103(1):1-11.

6. Eng CM, Fletcher J, Wilcox WR, Waldek S, Scott CR, Sillence DO, Breunig F, Charrow J, Germain DP, Nicholls K, et al. Fabry disease: baseline medical characteristics of a cohort of 1765 males and females in the Fabry Registry. J Inherit Metab Dis. 2007;30(2):184-92.

7. Giugliani R, Harmatz P, Wraith JE. Management guidelines for mucopolysaccharidosis VI. Pediatrics. 2007;120(2):405-18.
8. Mehta A, Ricci R, Widmer U, Dehout F, Garcia de Lorenzo A, Kampmann C, Linhart A, Sunder-Plassmann G, Ries M, Beck M. Fabry disease defined: baseline clinical manifestations of 366 patients in the Fabry Outcome Survey. Eur J Clin Invest. 2004;34(3):236-42.

9. Montano AM, Tomatsu S, Gottesman GS, Smith M, Orii T. International Morquio A Registry: clinical manifestation and natural course of Morquio A disease. J Inherit Metab Dis. 2007;30(2):165-74.

10. Pastores GM, Arn P, Beck M, Clarke JT, Guffon N, Kaplan P, Muenzer J, Norato DY, Shapiro E, Thomas J, et al. The MPS I registry: design, methodology, and early findings of a global disease registry for monitoring patients with Mucopolysaccharidosis Type I. Mol Genet Metab. 2007;91(1):37-47.

11. Weinreb NJ, Kaplan P. The history and accomplishments of the ICGG Gaucher registry. Am J Hematol. 2015;90 Suppl 1:S2-5.

12. Wraith JE, Beck M, Giugliani R, Clarke J, Martin R, Muenzer J, Investigators HOS. Initial report from the Hunter Outcome Survey. Genet Med. 2008;10(7):508-16.

13. Meikle PJ, Hopwood JJ, Clague AE, Carey WF. Prevalence of lysosomal storage disorders. JAMA. 1999;281(3):249-54.

14. Neufeld EF, Muenzer J. The Mucopolysaccharidoses. In: Scriver CR, Beaudet AL, Sly WS, Valle D, Childs B, Kinzler KW, Vogelstein B, editors. The Metabolic and Molecular Bases of Inherited Disease. 8th ed. New York: McGraw-Hill; 2001. p. 3421-52.

15. Tylki-Szymanska A. Mucopolysaccharidosis type II, Hunter's syndrome. Pediatr Endocrinol Rev. 2014;12 Suppl 1:107-13.

16. Baehner F, Schmiedeskamp C, Krummenauer F, Miebach E, Bajbouj M, Whybra C, Kohlschutter A, Kampmann C, Beck M. Cumulative incidence rates of the mucopolysaccharidoses in Germany. J Inherit Metab Dis. 2005;28(6):1011-7.

17. Guffon N, Bertrand Y, Forest I, Fouilhoux A, Froissart R. Bone marrow transplantation in children with Hunter syndrome: outcome after 7 to 17 years. J Pediatr. 2009;154(5):733-7.

18. Muenzer J, Beck M, Eng CM, Escolar ML, Giugliani R, Guffon NH, Harmatz P, Kamin W, Kampmann C, Koseoglu ST, et al. Multidisciplinary management of Hunter syndrome. Pediatrics. 2009;124(6):e1228-1239.

19. Muenzer J, Wraith JE, Beck M, Giugliani R, Harmatz P, Eng CM, Vellodi A, Martin R, Ramaswami U, Gucsavas-Calikoglu M, et al. A phase II/II clinical study of enzyme replacement therapy with idursulfase in mucopolysaccharidosis II (Hunter syndrome). Genet Med. 2006;8(8):465-73.

20. Muenzer J, Gucsavas-Calikoglu M, McCandless SE, Schuetz TJ, Kimura A. A phase I/I clinical trial of enzyme replacement therapy in mucopolysaccharidosis II (Hunter syndrome). Mol Genet Metab. 2007;90(3):329-37.

21. Muenzer J, Beck M, Eng CM, Giugliani R, Harmatz P, Martin R, Ramaswami U, Vellodi A, Wraith JE, Cleary M, et al. Long-term, open-labeled extension study of idursulfase in the treatment of Hunter syndrome. Genet Med. 2011;13(2):95-101.

22. Giugliani R, Hwu WL, Tylki-Szymanska A, Whiteman DA, Pano A. A multicenter, open-label study evaluating safety and clinical outcomes in children (1.4-7.5 years) with Hunter syndrome receiving idursulfase enzyme replacement therapy. Genet Med. 2014;16(6):435-41.

23. Cohn GM, Morin I, Whiteman DA, Hunter Outcome Survey I. Development of a mnemonic screening tool for identifying subjects with Hunter syndrome. Eur J Pediatr. 2013;172(7):965-70.

24. Jones SA, Almassy Z, Beck M, Burt K, Clarke JT, Giugliani R, Hendriksz C, Kroepfl T, Lavery L, Lin SP, et al. Mortality and cause of death in mucopolysaccharidosis type II-a historical review based on data from the Hunter Outcome Survey (HOS). J Inherit Metab Dis. 2009;32(4):534-43.

25. Kampmann C, Beck M, Morin I, Loehr JP. Prevalence and characterization of cardiac involvement in Hunter syndrome. J Pediatr. 2011;159(2):327-31. e322.

26. Keilmann A, Nakarat T, Bruce IA, Molter D, Malm G. Hearing loss in patients with mucopolysaccharidosis II: data from HOS - the Hunter Outcome Survey. J Inherit Metab Dis. 2012;35(2):343-53.

27. Link B, de Camargo Pinto LL, Giugliani R, Wraith JE, Guffon N, Eich E, Beck M. Orthopedic manifestations in patients with mucopolysaccharidosis type I (Hunter syndrome) enrolled in the Hunter Outcome Survey. Orthop Rev (Pavia). 2010;2(2):e16.

28. Mendelsohn NJ, Harmatz P, Bodamer O, Burton BK, Giugliani R, Jones SA, Lampe C, Malm G, Steiner RD, Parini R. Importance of surgical history in diagnosing mucopolysaccharidosis type II (Hunter syndrome): data from the Hunter Outcome Survey. Genet Med. 2010;12(12):816-22.

29. Parini R, Jones SA, Harmatz PR, Giugliani R, Mendelsohn NJ. The natural history of growth in patients with Hunter syndrome: Data from the Hunter Outcome Survey (HOS). Mol Genet Metab. 2016;117:438-56. 
30. Burton BK, Giugliani R. Diagnosing Hunter syndrome in pediatric practice: practical considerations and common pitfalls. Eur J Pediatr. 2012;171(4):631-9.

31. Alcalde-Martin C, Muro-Tudelilla JM, Cancho-Candela R, Gutierrez-Solana LG, Pintos-Morell G, Marti-Herrero M, Munguira-Aguado P, Galan-Gomez E. First experience of enzyme replacement therapy with idursulfase in Spanish patients with Hunter syndrome under 5 years of age: case observations from the Hunter Outcome Survey (HOS). Eur J Med Genet. 2010;53(6):371-7.

32. Burton BK, Guffon N, Roberts J, van der Ploeg AT, Jones SA. Home treatment with intravenous enzyme replacement therapy with idursulfase for mucopolysaccharidosis type II - data from the Hunter Outcome Survey. Mol Genet Metab. 2010;101(2-3):123-9.

33. Burton BK, Whiteman DA. Incidence and timing of infusion-related reactions in patients with mucopolysaccharidosis type II (Hunter syndrome) on idursulfase therapy in the real-world setting: a perspective from the Hunter Outcome Survey (HOS). Mol Genet Metab. 2011;103(2):113-20.

34. del Toro-Riera M. [Follow-up of patients with Hunter syndrome: the Hunter Outcome Survey (HOS) registry]. Rev Neurol. 2007;44 Suppl 1:S13-17.

35. del Toro-Riera M. World-wide experience in the treatment of mucopolysaccharidosis type II: the Hunter Outcome Survey (HOS) registry. RevNeurol. 2008;47(S02):S3-7.

36. Jones SA, Parini R, Harmatz P, Giugliani R, Fang J, Mendelsohn NJ. The effect of idursulfase on growth in patients with Hunter syndrome: Data from the Hunter Outcome Survey (HOS). Mol Genet Metab. 2013;109(1):41-8.

37. Muenzer J, Beck M, Giugliani R, Suzuki Y, Tylki-Szymanska A, Valayannopoulos V, Vellodi A, Wraith JE. Idursulfase treatment of Hunter syndrome in children younger than 6 years: results from the Hunter Outcome Survey. Genet Med. 2011;13(2):102-9.

38. Muenzer J. Early initiation of enzyme replacement therapy for the mucopolysaccharidoses. Mol Genet Metab. 2014;111(2):63-72.

39. Milligan A, Hughes D, Goodwin S, Richfield L, Mehta A. Intravenous enzyme replacement therapy: better in home or hospital? Br J Nurs. 2006;15(6):330-3.

40. Wiklund I, Raluy-Callado M, Stull DE, Jangelind Y, Whiteman DA, Chen WH. The Hunter syndrome-functional outcomes for clinical understanding scale (HS-FOCUS) questionnaire: evaluation of measurement properties. Qual Life Res. 2013;22(4):875-84

41. Wiklund I, Raluy-Callado M, Chen WH, Muenzer J, Fang J, Whiteman D. The Hunter Syndrome-Functional Outcomes for Clinical Understanding Scale (HS-FOCUS) Questionnaire: item reduction and further validation. Qual Life Res. 2014;23(9):2457-62.

42. Shapiro E, Bernstein J, Adams HR, Barbier AJ, Buracchio T, Como P, Delaney KA, Eichler F, Goldsmith JC, Hogan M, et al. Neurocognitive clinical outcome assessments for inborn errors of metabolism and other rare conditions. Mol Genet Metab. 2016;118(2):65-9.

43. Scarpa M, Almassy Z, Beck M, Bodamer O, Bruce IA, De Meirleir L, Guffon N, Guillen-Navarro E, Hensman P, Jones S, et al. Mucopolysaccharidosis type II: European recommendations for the diagnosis and multidisciplinary management of a rare disease. Orphanet J Rare Dis. 2011;6:72.

44. Sestito S, Ceravolo F, Grisolia M, Pascale E, Pensabene L, Concolino D. Profile of idursulfase for the treatment of Hunter syndrome. Res Repo Endoc Disord. 2015:5:79-90.

45. Martin R, Beck M, Eng C, Giugliani R, Harmatz P, Munoz V, Muenzer J. Recognition and diagnosis of mucopolysaccharidosis II (Hunter syndrome). Pediatrics. 2008;121(2):e377-386.

\section{Submit your next manuscript to BioMed Central and we will help you at every step:}

- We accept pre-submission inquiries

- Our selector tool helps you to find the most relevant journal

- We provide round the clock customer support

- Convenient online submission

- Thorough peer review

- Inclusion in PubMed and all major indexing services

- Maximum visibility for your research

Submit your manuscript at www.biomedcentral.com/submit
() Biomed Central 